\title{
Insulin and IGFs induce apoptosis in chick embryo retinas deprived of L-glutamine
}

\author{
Giuseppe Calvaruso ${ }^{1}$, Renza Vento ${ }^{1}$, Elvira Gerbino ${ }^{1}$, \\ Marianna Lauricella ${ }^{1}$, Maria Carabillò ${ }^{1}$, Helen Main ${ }^{1}$ and \\ Giovanni Tesoriere ${ }^{2}$ \\ ${ }^{1}$ Institute of Biological Chemistry, University of Palermo, Italy \\ 2 corresponding author: Istituto di Chimica Biologica Università di Palermo, \\ Policlinico, Via Del Vespro 12990127 Palermo, Italy. tel: +39 91655 2460; \\ fax: +39 91655 2449; email: gtesor@mbax.unipa.it
}

Received 29.7.96; revised 5.11.96; accepted 11.12.96 Edited by C.J. Thiele

\begin{abstract}
In chick embryo retinas, cultured in serum-free medium lacking L-glutamine, IGF-I, IGF-II and insulin induced apoptotic DNA fragmentation and cell death, IGF-I being the most efficacious compound. The apoptotic effect, which was particularly evident in retinas removed from 7-day-old chick embryos, declined with the age of the embryos and disappeared after day 11. Apoptosis appeared after a time lag of $8 \mathrm{~h}$ and then increased with time up to $16 \mathrm{~h}$. Cycloheximide, an inhibitor of protein synthesis, was capable of entirely abolishing apoptotic cell death. The effect induced by IGFs or insulin was suppressed by the addition of glutamine. Cytokine-mediated apoptosis was also observed after withdrawal of phosphate. We suggest that IGFs or insulin may produce, in retinas cultured in medium lacking L-glutamine or phosphate, a conflict of signals that could be lethal for retinal cells.
\end{abstract}

Keywords: apoptosis, chick embryo retina, development, growth factors

Abbreviations: b-FGF, basic fibroblast growth factor; $\mathrm{CHX}$, cycloheximide; EGF, epidermal growth factor; IGF, insulin-like growth factor; NGF, nerve growth factor

\section{Introduction}

The development and maintenance of tissues depends on a balance between different processes, such as proliferation, differentiation and cell death. During maturation of neural tissues overproduction of neurons is followed by programmed cell death which intervenes to eliminate unnecessary cells (Barinaga, 1993). It has been supposed that apoptosis also exerts a role during development of retinal tissues. In particular Ilschner and Waring (1992) have reported that the typical DNA fragmentation normally associated with apoptosis coincides in chick embryo retinas with retinal ganglion cell death. In addition apoptosis is the mechanism of cell death for several groups of lesions that injure photoreceptor cells (Chang et al, 1993; Portera-Cailliau et al, 1993; Tso et al, 1994; Steinberg, 1994).

In the last few years we have undertaken research employing chick embryo retinas cultured in vitro to understand the mechanisms and factors that contribute to the growth and development of retinas. This research has ascertained that chick embryo retina contains and synthesizes insulin (Tesoriere et al, 1994) and IGFs (Calvaruso et $a l, 1996)$ and that these compounds are capable of inducing the growth of retinas cultured in serum-free medium (Tesoriere et al, 1995; Calvaruso et al, 1996). Recently we have observed that glutamine deprivation causes a lowering of DNA synthesis in chick embryo retinas cultured in vitro (unpublished results). This observation agrees with the considerations previously made by many authors, that the absence of L-glutamine in the medium leads to an arrest of cell growth in G1 phase (Holley and Kiernan, 1974; Holley et al, 1978). Moreover, when insulin or IGF-I were added to retinas cultured in serum- and glutamine-free medium a further relevant lowering of DNA synthesis was observed, particularly in the youngest retinas studied (7-9 days) of 'in ovo' development (Tesoriere et al, 1992). This paper clearly demonstrates that the addition of IGF-I, IGF-II or insulin induces, in chick embryo retinas cultured in vitro without L-glutamine, DNA fragmentation and cell death via apoptosis. These results lead us to reinterpret the previously observed inhibitory effect of insulin on DNA synthesis in the light of the apoptotic effect exerted by the same compound.

\section{Results}

\section{Apoptosis in chick embryo retinas in ovo}

Apoptosis was assayed by means of a commercially available immunoassay for histone-associated DNA fragments described in Materials and Methods. In the first experiments, retinas removed from chick embryos at different ages were employed to evaluate the level of apoptosis during normal development. DNA fragmentation was found in retinas at all ages studied, with the maximum level at day 11 (Figure 1). These results confirm data previously reported by Ilshner and Waring (1992).

Induction of apoptosis in vitro: effect of insulin and IGFs in retinas deprived of either L-glutamine or phosphate

Studies on apoptosis in vitro were performed on 7-day-old chick embryo retinas (Figure $2 \mathrm{~A}$ ). When the retinas were incubated in complete serum-free medium, DNA fragmentation was unchanged with respect to the basal value even after $16 \mathrm{~h}$; while when they were cultured in serum-free medium 
deprived of L-glutamine a higher level of apoptosis (+20\%) was found. This level was further increased $(+93 \%)$ when insulin $(50 \mathrm{ng} / \mathrm{ml})$ was added to the culture medium. In previous studies, summarised in Figure $2 \mathrm{~B}$, we have demonstrated that DNA synthesis, measured in 7-day-old retinas after $16 \mathrm{~h}$ incubation in vitro, decreased $(-51 \%)$ when medium lacking L-glutamine was employed. The addition of insulin to the medium lacking L-glutamine caused a further decrease of this level by $69 \%$ (Tesoriere et al, 1992). In the light of these findings, we advance the hypothesis that this

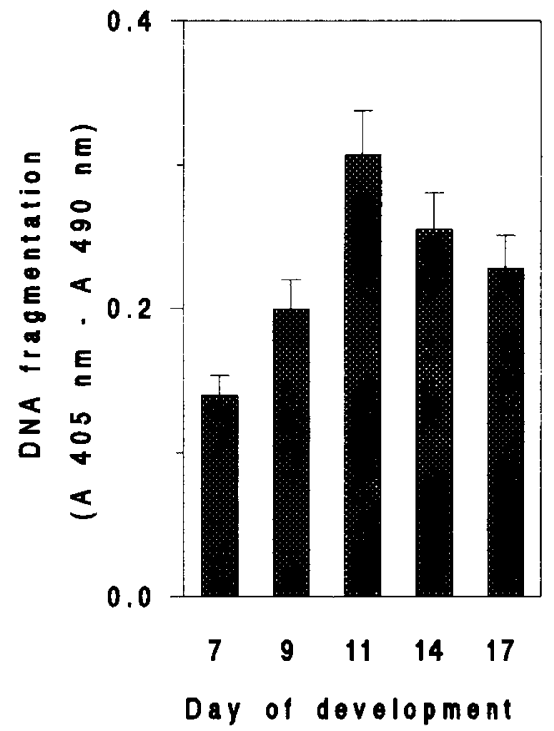

Figure 1 DNA fragmentation measured in chick embryo retinas at different days of 'in ovo' development. Retinas were removed from chick embryos at 7-17 days. DNA fragmentation was measured by means of ELISA kit as reported in Materials and Methods. Data represent the average ( \pm SEM) of five separate experiments.
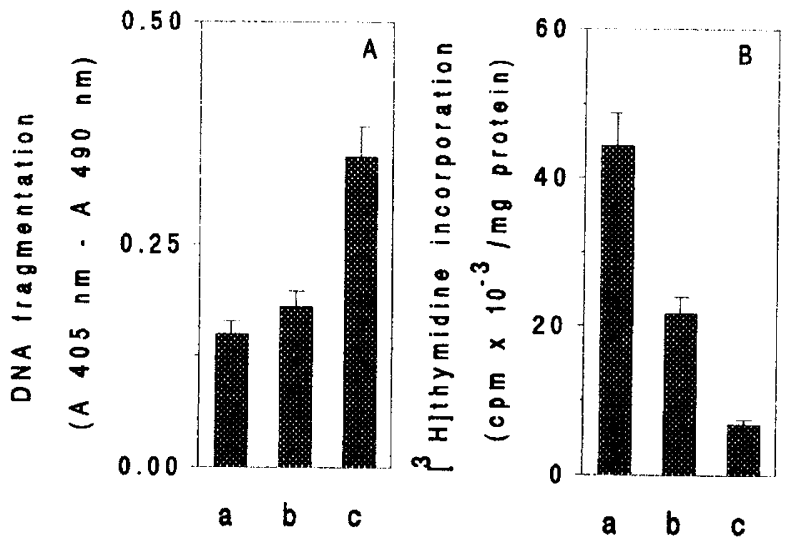

Figure 2 Effect of glutamine deprivation on DNA fragmentation A and DNA synthesis $\mathbf{B}$ in chick embryo retinas cultured in vitro. Retinas were removed from seven-day-old chick embryos and cultured in serum-free MEM containing L-glutamine $(292 \mathrm{mg} / \mathrm{L})$ a; without L-glutamine $\mathbf{b}$; without L-glutamine in the presence of insulin $(50 \mathrm{ng} / \mathrm{ml})$ c. After $16 \mathrm{~h}$, DNA fragmentation and $\left[{ }^{3} \mathrm{H}\right]$ thymidine incorporation were measured as reported in Materials and Methods. Data represent the average $( \pm$ SEM) of five separate experiments. further decrease in DNA synthesis could correspond to the effect exerted by insulin on DNA fragmentation.

The addition of L-glutamine to the medium reduced the effects determined by insulin in a dose-dependent fashion, so that at $200 \mathrm{mg} / \mathrm{L}$ the compound entirely abolished the modifications induced both to DNA fragmentation (Figure 3) and to DNA synthesis (data not shown). The formation of DNA fragments in response to insulin was also determined at different days of retina development. As Figure 4 shows, insulin exerted its apoptotic effect only in retinas between

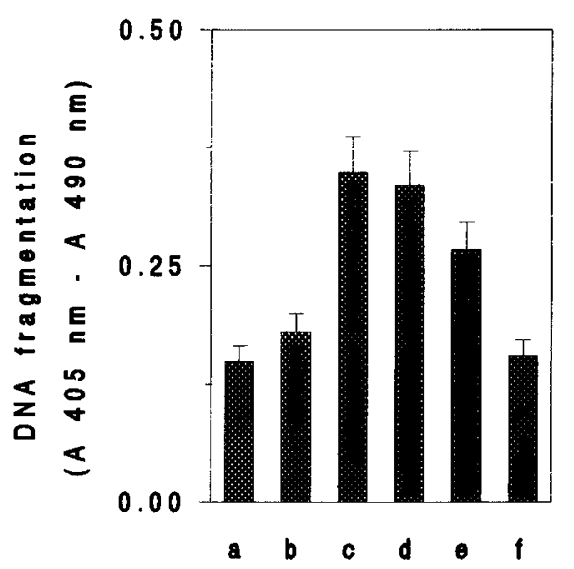

Figure 3 Influence of L-glutamine on the effect exerted by insulin on DNA fragmentation. Seven-day-old retinas were cultured in MEM with L-glutamine $(292 \mathrm{mg} / \mathrm{L}) \mathbf{a}$; without L-glutamine $\mathbf{b}$; without L-glutamine in the presence of insulin $(50 \mathrm{ng} / \mathrm{ml}) \mathbf{c}$; in the presence of insulin $(50 \mathrm{ng} / \mathrm{ml})$ with L-glutamine $(50 \mathrm{mg} / \mathrm{L}) \mathbf{d}$; $(100 \mathrm{mg} / \mathrm{L}) \mathbf{e}$; $(200 \mathrm{mg} / \mathrm{L}) \mathbf{f}$. After $16 \mathrm{~h}$ DNA fragmentation was measured as reported in Materials and Methods. Data represent the average $( \pm$ SEM) of five separate experiments.

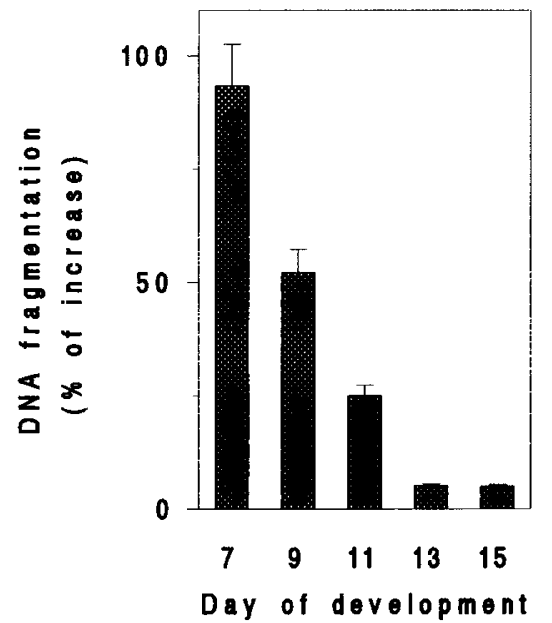

Figure 4 Effect of insulin on DNA fragmentation measured in chick embryo retinas at different days of development. Retinas were removed from chick embryos at 7-15 days and cultured in serum-free MEM deprived of L-glutamine in the presence of insulin $(50 \mathrm{ng} / \mathrm{ml})$. After $16 \mathrm{~h}$ DNA fragmentation was measured as reported in Materials and Methods. Data, expressed as percentages of increase in DNA fragmentation induced by insulin with respect to controls without insulin, represent the average $( \pm$ SEM) of three separate experiments. 
7-11 days, while it was not capable of inducing apoptosis in older retinas (13-15 days). In addition, it was observed that the younger the retina, the greater the apoptotic effect was.

As Figure 5A shows, both IGF I and IGF II caused, in chick embryo retinas cultured for $16 \mathrm{~h}$ in serum- and glutamine-free medium, DNA fragmentation at much lower concentrations than insulin. In fact IGF I increased DNA fragmentation by $92 \%$ at $2 \mathrm{ng} / \mathrm{ml}$ and IGF II showed similar effects at $10 \mathrm{ng} / \mathrm{ml}$, while insulin exerted the same effect at $50 \mathrm{ng} / \mathrm{ml}$. The effect seemed to be specific to the IGF family as other growth factors (EGF, bFGF, NGF) did not significantly modify the level of DNA fragmentation. Figure $5 \mathrm{~B}$ confirms that among the various growth factors tested, only insulin and IGFs were capable of inducing the characteristic ladder pattern of DNA fragmentation. Finally, data not shown demonstrated that IGFs, like insulin, exerted apoptotic effects only at ages of between 7 and 11 days.

We also evaluated whether other types of deprivation might predispose retinal cells to the apoptotic effect of insulin and IGFs. Phosphate deprivation, which, like glutamine deprivation, causes growth arrest in G1 (Holley and Kiernan, 1974), was employed to study such an effect. Data not shown demonstrated that when insulin was added to 7-day-old retinas incubated in medium lacking phosphate, DNA fragmentation increased after $16 \mathrm{~h}$ treatment by $77 \%$ with respect to retinas incubated without insulin. Measurements of $\left[{ }^{3} \mathrm{H}\right]$ thymidine incorporation into trichlor-

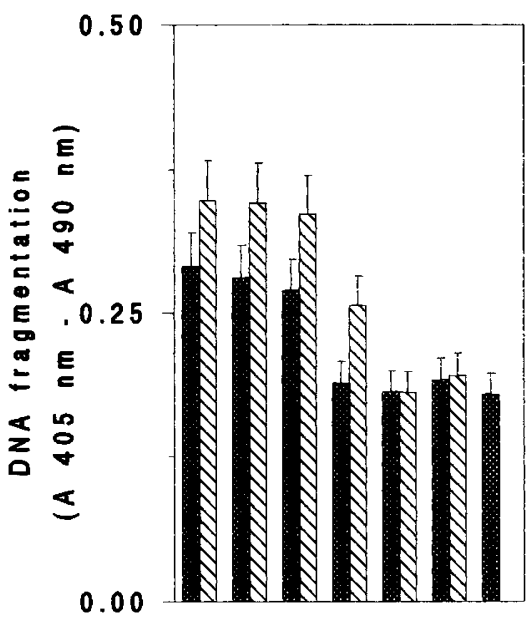

B
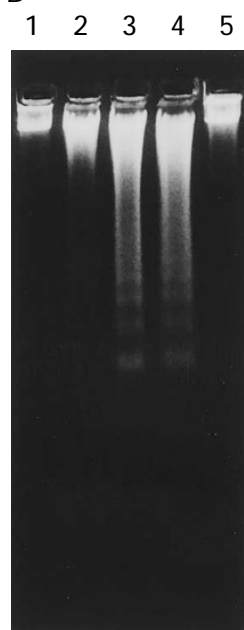

a b c d e f
Figure 5 The effects of various growth factors on apoptosis in chick embryo retinas in vitro. Seven-day-old retinas were cultured for $16 \mathrm{~h}$ in MEM without L-glutamine in the absence (control retinas) or in the presence of growth factors. A DNA fragmentation determined as described in Materials and Methods. Insulin (10 and $50 \mathrm{ng} / \mathrm{ml})$ a; IGF I $(0.2$ and $2 \mathrm{ng} / \mathrm{ml}) \mathbf{b}$; IGF II (1 and $10 \mathrm{ng} / \mathrm{ml}$ ) c; EGF (10 and $20 \mathrm{ng} / \mathrm{ml})$ d; bFGF (10 and $20 \mathrm{ng} / \mathrm{ml})$ e; NGF (10 and $20 \mathrm{ng} / \mathrm{ml}$ ) f; control g. Data are the average $( \pm S E M)$ of five separate experiments. B Agarose gel electrophoresis of DNA extracted from cultured retinas as reported in Materials and Methods. EGF $(20 \mathrm{ng} / \mathrm{ml})$ Lane 1; NGF $(20 \mathrm{ng} / \mathrm{ml})$ lane 2; insulin (50 ng/ml) lane 3; IGF I (2 ng/ml) lane 4; bFGF (20 ng/ $\mathrm{ml})$ lane 5 oacetic acid insoluble fraction showed that incubation for $16 \mathrm{~h}$ in medium lacking phosphate reduced DNA synthesis by $35 \%$; a further decrease $(-65 \%)$ was found when insulin $(50 \mathrm{ng} / \mathrm{ml})$ was added. These effects were progressively reduced by the addition of phosphate to the culture, disappearing when the concentration reached that present in complete medium $(160 \mathrm{mg} / \mathrm{L})$. Also in the case of phosphate deprivation, IGFs caused apoptosis at a much lower concentration than insulin.

\section{In situ labelling of fragmented DNA}

That insulin is capable of inducing the DNA fragmentation associated with apoptosis was also detected in situ by terminal transferase end-labelling (TUNEL). To this purpose 7-day-old chick embryo retinas were cultured for $16 \mathrm{~h}$ in serum- and glutamine-free medium with or without insulin and then processed as reported in Materials and Methods. Figure 6 shows sections of retinas treated with TdT and fluorescein-labelled dUTP and analysed under the fluorescence microscope. A much higher level of nuclear fragmentation was detected in retinas cultured in the presence of insulin (B) with respect to retinas cultured without insulin $(A)$.

A
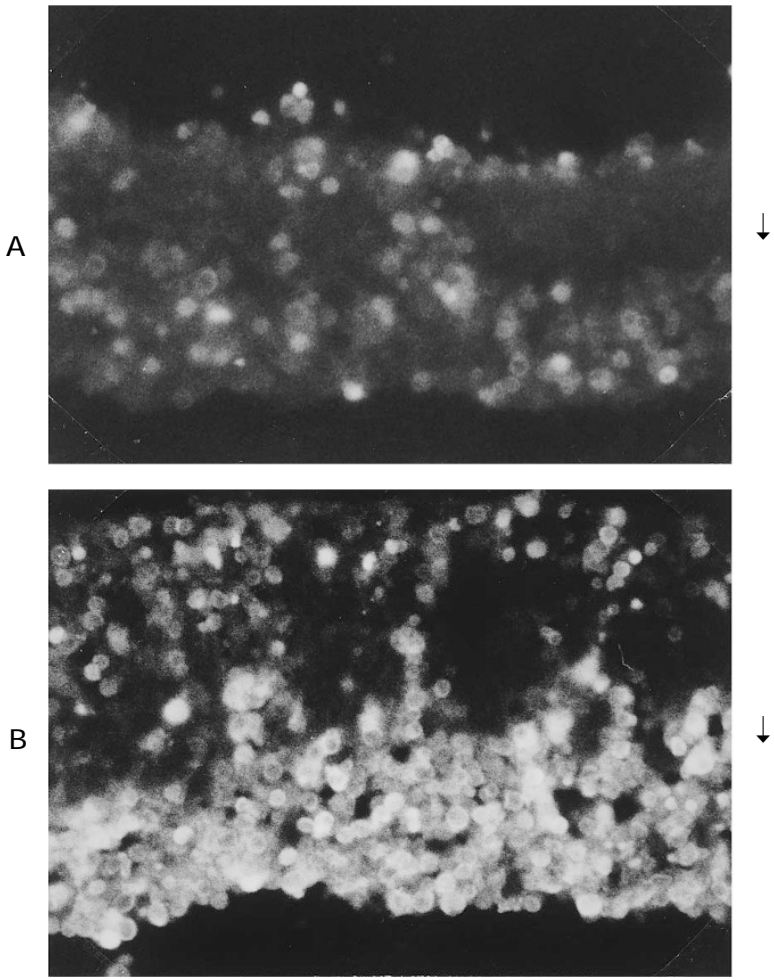

Figure 6 In situ detection of apoptotic cells in paraffin sections of chick embryo retina with the TUNEL method. Retinas were removed from 7-day-old chick embryos and placed in culture medium without $\mathbf{A}$ or with insulin $(50 \mathrm{ng} /$ $\mathrm{ml}$ ) B. After $16 \mathrm{~h}$ of incubation retinas were processed for histology and for TUNEL as described in Materials and Methods, and photographed under fluorescence microscope. Arrows indicate the direction of cellular layers from outer to inner. 


\section{The effect of insulin and IGFs is dose- and time- dependent}

Insulin affected both DNA synthesis and apoptosis in a dosedependent fashion (Figure 7). At $10 \mathrm{ng} / \mathrm{ml}$ insulin clearly determined both a reduction in DNA synthesis and an increase in DNA fragmentation. The two effects increased in correspondence as insulin concentration rose, reaching their maximum at $50-100 \mathrm{ng} / \mathrm{ml}$.

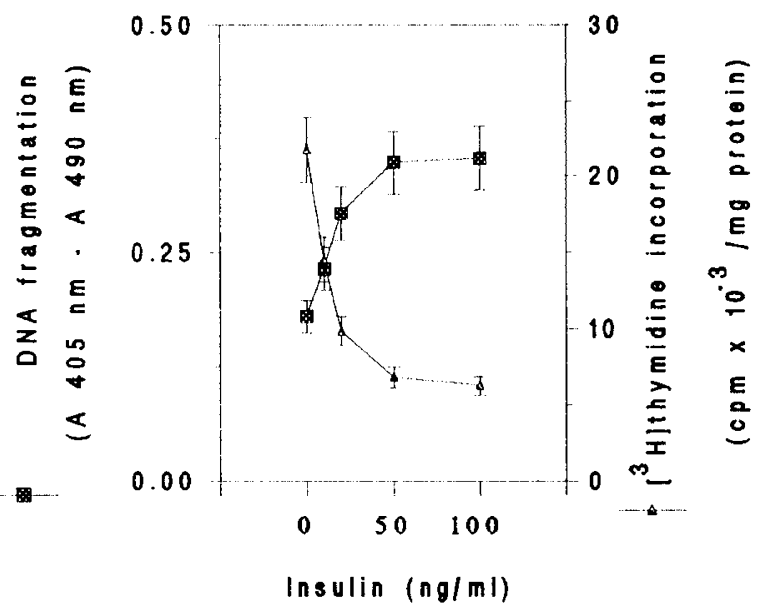

Figure 7 Dose-dependent effect of insulin on both DNA fragmentation and DNA synthesis in chick embryo retinas in vitro. Seven-day-old retinas were cultured for $16 \mathrm{~h}$ in the absence of L-glutamine with various concentrations of insulin. At the end DNA fragmentation and $\left[{ }^{3} \mathrm{H}\right]$ thymidine incorporation were measured as reported in Materials and Methods. Data are the average $( \pm$ SEM) of five separate experiments.

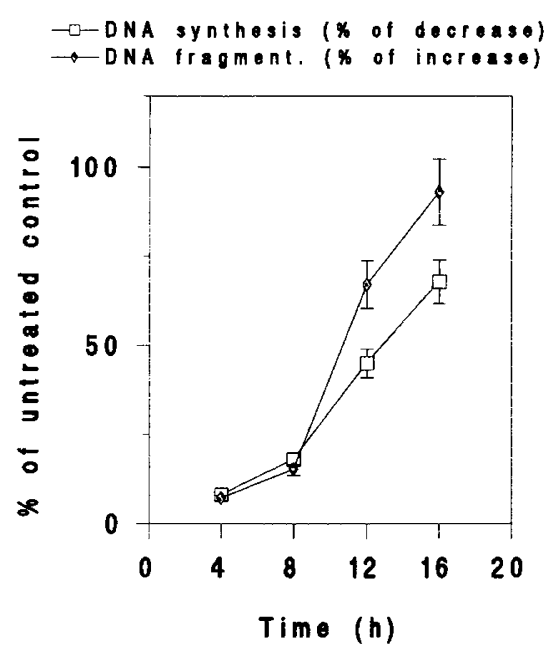

Figure 8 Time course of insulin effect on DNA fragmentation and on DNA synthesis in chick embryo retina cultured in vitro. Seven-day-old retinas were cultured without L-glutamine in the presence of insulin $(50 \mathrm{ng} / \mathrm{ml})$. At the indicated time intervals both DNA fragmentation and $\left[{ }^{3} \mathrm{H}\right]$ thymidine incorporation were measured. Results are expressed as \% of increase (DNA fragmentation) and as \% of decrease (DNA synthesis) with respect to control retinas which were cultured for identical times without both L-glutamine and insulin. Data are the average $( \pm$ SEM) of five separate experiments.
Figure 8 shows that the apoptotic effect induced by insulin, like the inhibitory effect exerted on DNA synthesis by the same compound, became apparent after at least $8 \mathrm{~h}$ of incubation, with both effects then increasing in parallel with time. Taken together, the results reported in Figures 7 and 8 show a close relationship between the effects determined by insulin on DNA synthesis and on apoptosis, and support the hypothesis that the decrement in DNA synthesis could be a consequence of apoptotic cell death.

IGF I and IGF II also induced apoptotic effects in a doseand time-dependent fashion. Like insulin, both IGF I and IGF II inhibited DNA synthesis at the same doses which induced apoptosis (data not shown). Furthermore, even when a medium lacking phosphate replaced medium lacking L-glutamine, the apoptotic effect induced by insulin and IGFs was dose- and time-dependent.

\section{Cycloheximide protects retinas from apoptosis}

Retinal apoptosis is an active process requiring new protein synthesis. This was ascertained by means of experiments intended to investigate the effects of cycloheximide (CHX), an effective inhibitor of protein synthesis, on insulin-induced death. As Figure 9A shows, $\mathrm{CHX}$ prevented, in a dosedependent fashion, the apoptosis induced by insulin in chick embryo retinas deprived of L-glutamine. Similar results were observed when $\mathrm{CHX}$ was employed to prevent IGF-I-induced cell death. These data are confirmed by the results reported in Figure $9 \mathrm{~B}$ in which the characteristic ladder pattern of DNA
A

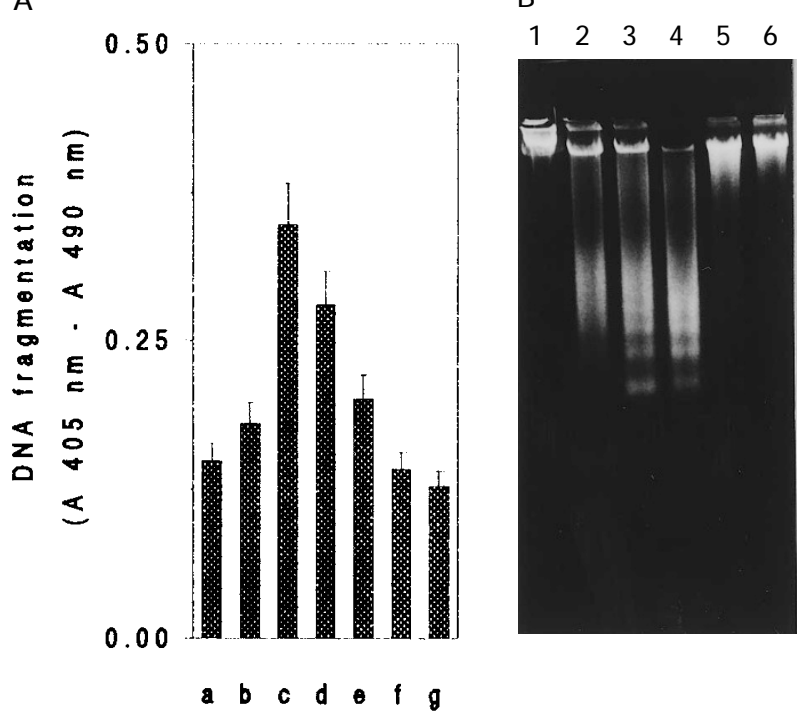

Figure 9 Effect of cycloheximide upon insulin-induced apoptosis in chick embryo retinas. A DNA fragmentation measured as reported in Materials and Methods. Data are the average $( \pm$ SEM) of five separate experiments. B Agarose gel electrophoresis of DNA extracted from chick embryo retinas as reported in Materials and Methods. Seven-day-old retinas were cultured for $16 \mathrm{~h}$ as follows: with glutamine $(292 \mathrm{mg} / \mathrm{L})$ a, lane 1 ; without L-glutamine $\mathbf{b}$, lane 2; without L-glutamine in the presence of insulin $(50 \mathrm{ng} / \mathrm{ml}) \mathbf{c}$, lane 3 ; without L-glutamine in the presence of IGF I $(1 \mathrm{ng} / \mathrm{ml}) \mathrm{d}$, lane 4 ; without L-glutamine in the presence of insulin plus $\mathrm{CHX}(10 \mu \mathrm{M})$ e or $(20 \mu \mathrm{M}) \mathrm{f}$, lane 5; without L-glutamine in the presence of IGF I plus $\mathrm{CHX}(20 \mu \mathrm{M}) \mathbf{g}$, lane 6. 
fragmentation, obtained when chick embryo retinas were cultured in the presence of insulin or IGF I, was abolished by the addition of $20 \mu \mathrm{M} \mathrm{CHX}$

\section{Content of glutamine in chick embryo retinas during development}

Because of the observed ability of glutamine to suppress the induction of apoptosis by insulin, we were interested in evaluating the concentration of glutamine in chick embryo retina during development. As Table 1 shows, the concentration of glutamine increases during the second week of development, reaching a maximum at day 14 , just when glutamine synthetase activity appears in retinas under glucocorticoid induction (Piddington, 1967). The content of glutamine was lower (85-103 $\mu \mathrm{g} / \mathrm{gl}$ wet weight) in the first stage of development studied (7-9 days) when the level of the compound depends solely on uptake from vitreous humor since chick embryo retina lacks blood vessels. The concentration of glutamine found at this stage of development would be, as suggested by the results reported in Figure 3 , low enough to permit locally produced cytokines (Calvaruso et al, 1996) to exert apoptotic effects.

\section{Discussion}

Our paper demonstrates that in retinas of chick embryos cultured in serum-free medium, the withdrawal of glutamine predisposes retinal cells to die via apoptosis by IGFs and insulin. We have also showed that cytokine-mediated apoptosis is not restricted to states of glutamine deprivation, but also appears in the presence of L-glutamine when phosphate-deprived media are employed. This apoptotic effect was induced by insulin and IGFs in 7-11 day-old chick embryo retinas. The effect was dose- and timedependent and was progressively suppressed by increasing glutamine concentration. The observation that apoptosis induced by IGFs or insulin was abrogated by cycloheximide, a potent inhibitor of protein synthesis, seems to indicate that the tissue is actively involved in its own demise.

In our experiments the apoptotic nature of cell death was shown by the demonstration of internucleosomal cleavage of retinal DNA, assessed both by a quantitative ELISA test that allows the calculation of the production of mono and oligonucleosomes, and by the ladder pattern of DNA fragments upon agarose gel electrophoresis. Moreover, that retinal cells die via apoptosis and not via primary

Table 1 Glutamine content in chick embryo retina during development

\begin{tabular}{lc}
\hline $\begin{array}{l}\text { Day of } \\
\text { development }\end{array}$ & $\begin{array}{c}\text { L-Glutamine } \\
(\mu \mathbf{g} / \mathbf{g r} \text { wet weight })\end{array}$ \\
\hline VII & $85.4 \pm 10.5$ \\
IX & $103.3 \pm 12.5$ \\
XI & $113.8 \pm 13.1$ \\
XIV & $125.3 \pm 14.4$ \\
XVI & $118.4 \pm 12.3$ \\
XVIII & $121.2 \pm 15.6$ \\
\hline
\end{tabular}

Amino acids were derivatized and separated by means of reverse phase HPLC. Glutamine was quantified as reported in Materials and Methods. Values are means \pm SEM of three independent experiments. necrosis was demonstrated by the TUNEL method (Gavrieli et al, 1992) which is a useful procedure for the in situ identification of programmed cell death.

Apoptosis seemed to be induced specifically by insulin or IGFs, as no other tested growth factors (EGF, bFGF, NGF) exhibited any detectable apoptotic activity, even when present at high concentrations. Since the apoptotic effect of IGFs was obtained at a much lower concentration than insulin, we hypothesise that these cytokines could induce their effect through IGF receptors. To this purpose we have recently demonstrated the presence in chick embryo retina of type I IGF receptor with high affinity for IGFs and much lower affinity for insulin (Calvaruso et al, 1996).

Previously (Tesoriere et al, 1989a) we purified from foetal calf serum a $7 \mathrm{kDa}$ polypeptide that markedly decreased DNA synthesis in retinas cultured in serum- and glutaminefree medium. We have now ascertained that this polypeptide markedly induces apoptosis as IGFs and insulin do, is capable of immunoreacting with IGF I antibody and, when submitted to HPLC on a reversed-phase C18 column, is eluted in complete coincidence with IGF I immunoreactivity (data not shown). These findings suggest that the inhibitory peptide could be recognised as IGF I.

However, differently from what is reported in this paper, some authors have demonstrated that a restricted group of cytokines, such as IGFs and PDGF, is capable of completely inhibiting the apoptotic death induced in serum-deprived fibroblasts by deregulated expression of c-myc and that this inhibition of apoptosis occurs in the absence of protein synthesis and is independent of the cell cycle phase (Evan et al, 1992; Harrington et al, 1994).

As our experiments demonstrate, the highest level of apoptotic effect was found in retinas removed from the youngest embryos studied (day 7 of development). At this age the cell population of the retina is represented only by morphologically undifferentiated retinoblasts (Tesoriere et al, 1995) which possess high proliferative ability (Tesoriere et al, 1989b). After day 7 the level of cytokine-induced apoptosis lowers with the age of the embryos, reaching its lowest value at day 11. The observation that the level of DNA synthesis decreased in a similar fashion, (Tesoriere et al, 1989b), suggests a relationship between the capacity of retinas to undergo apoptosis by insulin or IGF-I and their proliferative ability, which is dependent on the presence of immature retinoblasts. As shown in this paper, a necessary condition for insulin or IGF-I to induce apoptosis in the retinas is incubation in a medium deprived of glutamine or phosphate. It is well known that deprivation of nutrients arrests the growth of cells cultured in vitro and favours the shift between proliferative and quiescent states (Holley and Kiernan, 1974; Holley et al, 1978). The addition to serum- and glutamine-free medium of IGF-I or insulin, compounds which are known to stimulate cell growth, may produce an unresolved conflict of signals that could be lethal for retinal cells.

It is known that in the nervous system, particularly in the retina (Young, 1984), cell death is associated with modulating the interconnections in cell populations during normal development of neurons (Oppenheim, 1991). Our results suggest that insulin and IGFs could take part in the apoptotic programme associated with retinal development and that the 
ability of these compounds to stimulate apoptosis could be under the control of the glutamine concentration in the tissue. Thus, it seems possible that in the early stages of chick embryo retina development, between $7-9$ days, the low level of glutamine concentration could permit apoptotic intervention by IGFs or insulin. IGF I seems more involved in this process than insulin, as IGF I is capable of inducing cell death at a lower concentration. Furthermore, the content of IGF-I, found in the retina at days 7-9 of development, was about $110 \mathrm{ng} / \mathrm{g}$ of tissue and that of IGF-II about $300 \mathrm{ng} / \mathrm{g}$ of tissue (Calvaruso et al, 1996), much higher concentrations than those employed in the experiments reported in this paper to induce apoptotic cell death.

Apart from the role that cytokine-induced apoptosis assumes during retinal development, we believe that it could represent a useful model both for studying the apoptotic mechanism in vitro and identifying the specific gene products associated with apoptosis.

\section{Materials and Methods}

\section{Retinal Explants}

Eggs of uniform size and weight were placed in an automatic incubator (Victoria) at $38^{\circ} \mathrm{C}$ and $60 \%$ relative humidity. Unless otherwise stated, 7-day-old retinas were removed from chick embryos (Tesoriere et al, 1992) and explants were incubated $16 \mathrm{~h}$ at $37^{\circ} \mathrm{C}$ in serum-free medium deprived of L-glutamine (1 retina/2 $\mathrm{ml}$ ) with or without cytokines.

\section{Quantification of DNA fragmentation}

Quantification of apoptosis was carried out using a photometric cell death detection ELISA kit (Boehringer, Mannheim) that measures cytosolic DNA-histone complexes produced as a consequence of apoptotic DNA fragmentation. The assay is based on the quantitative sandwich-enzyme-immunoassay principle using mouse monoclonal antibodies directed against DNA and histones, respectively. ELISA may be applied to measure apoptotic cell death in cytoplasmic fractions of cell lines or tissue homogenates (Leist et al, 1994; Sumantran et al, 1995). Chick embryo retinas were washed twice with culture medium and homogenized following the manufacturer's instructions. After centrifugation at $20,000 \times \mathrm{g}$, the cytosolic fraction was employed to measure DNA-histone complexes. In particular, amounts of proteins $(50 \mathrm{ng}$ ) were applied to ELISA plates coated with the capture anti-histone antibody Mab (clone $\mathrm{H} 11-4$ ) and incubated for $90 \mathrm{~min}$ at room temperature. After three washes, anti-DNA-peroxidase antibody was added for $90 \mathrm{~min}$ at room temperature and the wells washed three times. Visualization was by addition of the substrate ABTS [2,2'-azino-di-(3-ethylbenzthiazoline sulphonate)] and the optical density of the plate was read at $405 \mathrm{~nm}$ (test wave length) and at $490 \mathrm{~nm}$ (reference wave length).

\section{In situ cell death detection (TUNEL)}

For the preparation of retinal tissue sections we followed the protocol developed by Gavrieli et al (1992) with some modifications. Day 7 chick embryo retinas were incubated in serum-free MEM deprived of L-glutamine with or without insulin $(50 \mathrm{ng} / \mathrm{ml})$. After $16 \mathrm{~h}$ retinas were immersed in $4 \%$ buffered formaldehyde for $12 \mathrm{~h}$ at $4{ }^{\circ} \mathrm{C}$. Dehydration, clearing and embedding in paraffin wax were performed as conventionally. Paraffin sections $(5 \mu \mathrm{m})$ were adhered to slides pretreated with $0.01 \%$ aqueous solution of poly-L-lysine (300,000 mol. wt.; Sigma Chemical Co., St. Louis, MO). After deparaffination and rehydration, apoptotic DNA fragmentation was detected by TUNEL method using the 'In situ cell death detection kit, AP' (Boehringer Mannheim GmbH) for immunohistochemical detection at single cell level. In particular, sections were digested with proteinase $\mathrm{K}$, rinsed with bidistilled water and the $3^{\prime}$-ends of DNA fragments were labelled with terminal deoxynucleotidyl transferase (TdT) and fluorescein-labelled dUTP. Negative controls included substitution of water for TdT in the reaction buffer. Slides were analyzed and photographed under fluorescence microscope.

\section{Assessment of apoptosis by agarose gel electrophoresis}

Retinas were washed twice in saline and broken up by freezing $\left(-80^{\circ} \mathrm{C}\right)$ and thawing. Samples were resuspended in lysis buffer ( $1 \mathrm{ml} / 100 \mathrm{mg}$ retina) composed of $25 \mathrm{mM}$ EDTA; $100 \mathrm{mM} \mathrm{NaCl}$; $10 \mathrm{mM}$ Tris- $\mathrm{HCl}, \mathrm{pH} 8.0 ; 0.5 \%(\mathrm{w} / \mathrm{v})$ SDS and $0.2 \mathrm{mg} / \mathrm{ml}$ proteinase $\mathrm{K}$. The suspensions were incubated overnight at $37^{\circ} \mathrm{C}$ and DNA was extracted following the procedure described by Ilschner and Waring (1992). Electrophoresis of fragmented DNA was carried out on $1.5 \%$ agarose gel containing $0.5 \mathrm{mg} / \mathrm{ml}$ ethidium bromide. Before electrophoresis, loading buffer (10 mM EDTA, $0.25 \%$, w/v, bromophenol blue, $0.25 \%$, w/v, xylene cyanole FF and $50 \%$ glycerol) was added to each sample in a $1: 5$ ratio. Samples were then heated to $65^{\circ} \mathrm{C}$ for $10 \mathrm{~min}$ and plunged into ice. $10 \mu \mathrm{g}$ of DNA were loaded into each well and electrophoresis was carried out at 60 volts in Tris-Borate/EDTA Electrophoresis Buffer for $2 \mathrm{~h}$. A Hind III digest of $\lambda$ DNA was applied as standard. The gel was photographed under UV-light.

\section{Glutamine assay}

Chick embryo retinas were homogenized in $0.3 \mathrm{M}$ cold perchloric acid $(1: 5 \mathrm{w} / \mathrm{v})$ and centrifuged at $35,000 \times \mathrm{g}$ for $20 \mathrm{~min}$ at $4^{\circ} \mathrm{C}$. Neutralized supernatants were employed for amino acid derivatization with dimethylaminoazobenzene sulphonyl chloride. Aliquots were injected into a $5 \mu \mathrm{m}$ Spherisorb HPLC column C18 RP $(25 \mathrm{~cm} \times 4.6 \mathrm{~mm}$ i.d. $)$ which was eluted with a mobile phase consisting of two eluents: $25 \mathrm{mM}$ potassium dihydrogen phosphate, $\mathrm{pH}$ 6.8; and acetonitrile-2propanol $(75: 25 ; \mathrm{v} / \mathrm{v})$ (Stocchi et al, 1989). The detection was performed at $436 \mathrm{~nm}$ with a UV/visible HPLC detector (Gilson). Glutamine was quantified by comparison with known concentrations of authentic L-glutamine derivatives separated under the same experimental conditions.

\section{Measurements of DNA synthesis}

To evaluate DNA synthesis in retinas cultured in vitro, retinas from 7day old chick embryos were incubated in serum-free MEM deprived of L-glutamine (1 retina/2 $\mathrm{ml}$ ) with or without insulin or IGF-I. After $16 \mathrm{~h}$ the medium was substituted with $2 \mathrm{ml}$ fresh medium containing $1 \mu \mathrm{l}$ $\left[{ }^{3} \mathrm{H}\right]$ thymidine $(6.7 \mathrm{Ci} / \mathrm{mmol}$, DuPont NEN) and the incubation was protracted for $30 \mathrm{~min}$. At the end, $\left[{ }^{3} \mathrm{H}\right]$ thymidine incorporation into trichloroacetic acid insoluble fraction was determined as previously reported (Tesoriere et al, 1992).

Protein content was estimated according to Lowry et al (1951) using bovine serum albumin as standard.

\section{Acknowledgements}

We are especially indebted to the Associazione Italiana per la Ricerca sul Cancro (AIRC, Milano) for financial support. This research was also 
partially supported by Ministero della Università e della Ricerca Scientifica e Tecnologica (MURST, Roma). We are indebted to Prof. A. Giammanco for her practical support.

\section{References}

Barinaga M (1993) Death gives birth to the nervous system. But how? Science 259 $762-763$

Calvaruso G, Vento R, Giuliano M, Lauricella M, Gerbino E and Tesoriere G (1996) Insulin-like growth factors in chick embryo retina during development Regul. Pept. 61: 19-25

Chang GQ, Hao $Y$ and Wong F (1993) Apoptosis: Final common pathway of photoreceptor death in rd, rds, and rhodopsin mutant mice. Neuron 11: 595-605

Evan GI, Wyllie AH, Gilbert CS, Littlewood T, Land H, Brooks M, Waters CM, Penn LZ and Hancock CL (1992) Induction of apoptosis in fibroblasts by c-Myc protein. Cell 69: $119-128$

Gavrieli Y, Sherman Y and Ben-Sasson SA (1992) Identification of programmed cell death in situ via specific labeling of nuclear DNA fragmentation. The J. Cell Biol. 119: 493-501

Harrington EA, Bennet MR, Fanidi A and Evan GI (1994) c-myc-induced apoptosis in fibroblasts is inhibited by specific cytokines. EMBO J. 13: 3286-3295

Holley RW and Kiernan JA (1974) Control of the initiation of DNA synthesis in 3T3 cells: low-molecular-weight nutrients. Proc. Natl. Acad. Sci. USA 71: $2942-$ 2945

Holley RW, Armour R and Baldwin JH (1978) Density-dependent regulation of growth of BSC-1 cells in cell culture: control of growth by low molecular weight nutrients. Proc. Natl. Acad. Sci. USA 75: 339-341

Ilschner SU and Waring P (1992) Fragmentation of DNA in the retina of chicken embryos coincides with retinal ganglion cell death. Biochem. Biophys. Res. Comm. 183: 1056-1061

Leist M, Gantner F, Bohlinger I, Germann PG, Tiegs G and Wendel A (1994) Murine hepatocyte apoptosis induced in vitro and in vivo by TNF- $\alpha$ requires transcriptional arrest. The J. Immunol. 153: 1778-1788

Lowry OH, Rosebrough NJ, Farr AL and Randall RJ (1951) Protein measurement with the Folin phenol reagent. J. Biol. Chem. 193: 265-275
Oppenheim RW (1991) Cell death during development of the nervous system. Annu. Rev. Neurosci. 14: 453-501

Piddington R (1967) Hormonal effects on the development of glutamine synthetase in the embryonic chick retina. Dev. Biol. 16: 186-188

Portera-Cailliau C, Sung CH, Nathans J and Adler R (1993) Apoptotic photoreceptor cell death in mouse models of retinitis pigmentosa. Proc. Natl. Acad. Sci. USA 91: 974-978

Steinberg RH (1994) Survival factors in retinal degenerations. Curr. Op. Neurobiol. 4 : $515-524$

Stocchi V,Piccoli G, Magnani M, Palma F, Biagiarelli B and Cucchiarini L (1989) Reversed-phase high-performance liquid chromatography separation of dimethylaminoazobenzene sulfonyl-and dimethylaminobenzene thiohydantoin-amino acid derivatives for amino acid analysis and microsequencing studies at the picomole level. Anal. Biochem. 178: 107-117

Sumantran VN, Ealovoga MW, Nuñez G, Clarke MF and Wicha MS (1995) Overexpression of $\mathrm{Bcl}-\mathrm{x}_{\mathrm{s}}$ sensitizes MCF-7 cells to chemotherapy-induced apoptosis. Cancer Res. 55: 2507-2510

Tesoriere G, Vento R, Calvaruso G, Schiavo MR, Giuliano M and Taibi G (1989a) Inhibition of DNA synthesis in chick embryo retinas, in vitro, by a factor from fetal bovine serum. Dev. Brain Res. 47: 19-25.

Tesoriere G, Vento R, Taibi G, Calvaruso G and Schiavo M R (1989b) Biochemical aspects of chick embryo retina development: the effect of glucocorticoids. J. Neurochem. 52: 1487-1494.

Tesoriere G, Vento R, Calvaruso G, Taibi G and Giuliano M (1992) Identification of insulin in chick embryo retina during development and its inhibitory effect on DNA synthesis. J. Neurochem. 58: 1353-1359

Tesoriere G, Calvaruso G, Vento R, Giuliano M, Lauricella M and Carabillò M (1994) Insulin synthesis in chick embryo retinas during development. Neurochem. Res. 19: $821-825$

Tesoriere G, Vento R, Morello V, Tomasino RM, Carabillò M and Lauricella M (1995) Chick embryo retina development in vitro: the effect of insulin. Neurochem. Res. 20: $803-813$

Tso MOM, Zhang C, Abler A, Chang CJ, Wong F, Chang GQ and Lam TT (1994) Apoptosis leads to photoreceptor degeneration in inherited retinal dystrophy of RCS rats. Invest. Ophthal. Vis. Sci. 35: 2693-2699

Young RW (1984)Cell death during differentiation of the retina in the mouse. J. Comp. Neurol. 229: 362-373 